\title{
PELAKSANAAN PENILAIAN AUTENTIK ASPEK PENGETAHUAN, SIKAP DAN KETERAMPILAN DI SEKOLAH ATAU MADRASAH
}

\author{
Wildan \\ Universitas Islam Negeri (UIN) Mataram \\ wildan.mataram@gmail.com
}

\begin{abstract}
Abstrak
Penilaian merupakan proses yang sistematis, dengan mengumpulkan berbagai informasi, baik berupa data angka maupun deskripsi verbal. Penilaian yang dilakukan guru di sekolah, sekurang-kurangnya dimaksudkan untuk (1) mengetahui penguasaan siswa terhadap materi pembelajaran dan (2) mengetahui keefektifan proses pembelajaran yang telah berlangsung. Selain itu evaluasi juga dimaksudkan untuk mengetahui dampak penguasaan siswa terhadap perubahan prilaku siswa dalam kehidupan sehari-hari, baik di sekolah maupun di lingkungan sekitarnya. Penilaian yang dilakukan terbatas pada aspek tertentu saja tidak dapat dijadikan sebagai satu-satunya dasar pengambilan keputusan terhadap perkembangan siswa. Oleh karena itu guru memerlukan instrument penilaian yang beragam. Kajian ini menemukan bahwa penilaian autentik lebih bermakna secara signifikan dibandingkan dengan tes pilihan ganda terstandar sekalipun. Penilaian autentik juga diartikan sebagai proses pengumpulan informasi oleh guru tentang perkembangan dan pencapaian pembelajaran yang dilakukan anak didik melalui berbagai teknik yang mampu mengungkapkan, membuktikan atau menunjukkan secara tepat pada tujuan pembelajaran dan kemampuan (kompetensi) telah benar-benar dikuasai dan dicapai.
\end{abstract}

Kata Kunci: Penilaian Autentik; Penilaian Pengetahuan; Penilaian Sikap; Penilaian Keterampilan;

\section{PENDAHULUAN}

Kegiatan pembelajaran sebagai sebuah sistem terdiri dari komponenkomponen guru, siswa, tujuan, bahan materi, fasilitas, strategi dan penilaian. Keseluruhan komponen tersebut tidak dapat berdiri sendiri, komponen satu dengan komponen lainnya saling berhubungan. Guru tidak dapat dilepaskan dari siswa yang menjadi sasaran dalam proses pembelajaran. Dalam proses pembelajaran yang dilaksanakan guru harus memiliki tujuan yang jelas, dengan berbagai bahan materi yang harus dipenuhi untuk mencapai tujuan 
Wildan (2017). PELAKSANAAN PENILAIAN AUTENTIK ASPEK PENGETAHUAN, SIKAP DAN KETERAMPILAN DI SEKOLAH ATAU MADRASAH. JURNAL TATSQIF, 15(2), Retrieved from: http://ejurnal.iainmataram.ac.id/index.php/tatsqif/article/view/1459.

yang telah direncanakkan. Dalam prosesnya seorang guru harus menggunakan berbagai cara sebagai strategi dalam menyajikan materi kepada siswa yang didukung oleh berbagai fasilitas memadai guna memudahkan siswa dalam belajar. Pada akhirnya guru harus dapat mengukur ketercapaian tujuan, maupun efektifitas proses pembelajaran melalui penilaian.

Komponen penilaian menjadi bagian yang tidak boleh ditinggalkan dalam proses pembelajaran. Karena dengan penilaian guru akan dapat mengukur penguasaan kompetensi siswa, juga dapat dijadikan sebagai umpan balik bagi guru untuk memperbaiki proses pembelajaran agar semakin efektif. Selain itu guru juga dapat menggunakan hasil penilaian sebagai bahan pertimbangan untuk mengambil keputusan tentang siswa, sehingga dapat dijadikan sebagai bahan laporan kepada orang tua siswa. Penilaian ini juga tidak terlepas dari maskud untuk mempertimbangkan apakah siswa dapat mempelajari materi untuk kompetensi berikutnya, ataukah siswa harus diberikan kesempatan untuk mempelajari ulang sampai materi pada kompetensi tersebut dapat dikuasai dengan baik. Dengan demikian hasil penilaian dapat digunakan sebagai dasar untuk melaksanakan remedial dan pengayaan.

Penilaian yang dilakukan oleh guru seharusnya bersifat konprehensif, penilaian yang dimaksudkan untuk mendapatkan informasi pada seluruh aspek perkembangan siswa, baik aspek kognitif, afektif maupun psikomotorik. Penilaian yang dilakukan terbatas pada aspek tertentu saja, tidak dapat dijadikan sebagai satu-satunya dasar pengambilan keputusan terhadap perkembangan siswa. Oleh karena itu guru memerlukan instrument penilaian yang berbeda untuk mengukur aspek perkembangan siswa yang berbeda pula.

Penilaian yang melingkupi seluruh aspek perkembangan siswa sebagaimana dimaksudkan di atas sebenarnya telah ada tidak hanya di dalam kurikulum 2013, tetapi ada di dalam setiap kurikulum sebelumnya. Penilaian sebagai komponen tidak terpisahkan dalam pembelajaran harus direncanakan guru sejak awal sebelum kegiatan pembelajaran dilaksanakan. 
Penilaian yang direncanakan tersebut disusun sebagai acuan pendidik, maupun satuan pendidikan dalam mengukur ketercapaian tujuan pendidikan dan pembelajaran secara keseluruhan. Dalam Permendikbud nomor 66 tahun 2013 menyebutkan bahwa penilaian harus menjamin :

- perencanaan penilaian peserta didik sesuai dengan kompetensi yang akan dicapai dan berdasarkan prinsip-prinsip penilaian;

- pelaksanaan penilaian peserta didik secara profesional, terbuka, edukatif, efektif, efisien, dan sesuai dengan konteks sosial budaya; dan

- pelaporan hasil penilaian peserta didik secara objektif, akuntabel, dan informative (Permendikbud Nomor 66 tahun 2013).

Penilaian yang dilakukan haruslah terbuka, siswa harus mendapatkan informasi tentang jenis penilaian, teknik maupun penskoran serta kapan waktu penilaian tersebut akan dilakukan. Selain itu penilaian harus mencerminkan konteks social siswa bukan menilai tentang sekolah. Hasil penilaian yang telah dilaksanakan baik berupa data angka maupun data verbal harus dilaporkan secara obyektif dan dapat dipertanggungjawabkan, serta mampu memberikan informasi yang akurat baik bagi siswa maupun orang tua siswa.

Umumnya masih ditemukan bahwa guru mengembangkan instrument penilaian sesaat sebelum penilaian akan dilaksanakan. Guru seharusnya telah mempersiapkan seluruh rencana kegiatan pembelajaran termasuk mengembangkan instrument penilaian sebelum kegiatan pembelajaran dilaksanakan. Selain itu instrument penilaian yang dikembangkan guru masih didominasi oleh instrument penilaian yang digunakan untuk mengukur aspek kognitif. Sedangkan instrumen penilaian untuk aspek psikomotorik apalagi untuk aspek afektif belum banyak dikembangkan. Hal ini terjadi dapat saja disebabkan oleh sistem yang berpengaruh terhadap sistem penilaian di madrasah/sekolah yang selama ini lebih banyak menekankan kepada aspek kognitif. Dapat pula dimungkinkan juga karena kurangnya kemampuan guru dalam mengembangkan instrument penilaian untuk aspek psikomotorik dan aspek afektif. 


\section{METODE PENULISAN}

Penulisan dalam artikel ini menggunakan metode studi pustaka (library research). Penulis mengumpulkan sejumlah referensi tentang penilaian autentik baik dari buku, jurnal, maupun dokumen peraturan pemerintah yang terkait. Referensi tersebut dikaji secara seksama untuk memperoleh penjelasan yang rinci terkait penilaian autentik di dunia pendidikan. Mengacu pada kajian tersebut, peneliti kemudian merumuskan pandangannya mengenai pelaksanaan penilaian autentik di sekolah atau madrasah yang meliputi penilaian pada domain pengetahuan, sikap dan keterampilan.

\section{HASIL DAN PEMBAHASAN}

Penilaian merupakan kegiatan akhir dari setiap proses pembelajaran yang telah direncanakan. Penilaian ini tentunya bertujuan untuk mengukur penguasaan siswa terhadap materi dan tujuan pembelajaran yang telah dipelajari, serta dapat digunakan untuk mengukur keefektifan sebuah kegiatan pembelajaran. Namun demikian kegiatan penilaian tidak selalu dilaksanakan satu kali setelah menyelesaikan seluruh rangkaian kegiatan pembelajaran, akan tetapi dapat dilaksanakan pada setiap menyelesaikan setiap tahapan proses sebelum menyelesaikan seluruh proses pembelajaran. Penilaian seperti ini biasanya dikenal dengan penilaian formatif, sedangkan penilaian yang dilaksanakan setelah menyelesaikan seluruh rangkaian proses pembelajaran dikenal dengan penilaian sumatif.

Dengan demikian penilaian formatif lebih dimanfaatkan untuk memperbaiki proses pembelajaran yang sedang berlangsung, sedangkan penilaian sumatif lebih dimaksudkan untuk mengukur kemampuan dan perkembangan siswa pada keseluruhan aspek baik afektif, pengetahuan dan psikomotorik.

Penilaian, sebagaimana telah diungkapkan di atas merupakan bagian yang tidak terlepas dari kegiatan pembelajaran. Penilaian merupakan proses pengumpulan informasi mengenai keadaan siswa baik dalam bentuk data 
angka maupun data verbal yang digunakan sebagai bahan pertimbangan dalam mengambil keputusan tentang siswa. Penilaian merupakan proses yang sistematis, dengan mengumpulkan berbagai informasi, baik berupa data angka maupun deskripsi verbal. Data dimaksud kemudian dianalisis, dan dinterpretasi untuk membuat keputusan. Dengan demikian dapat disimpulkan bahwa penilaian merupakan proses pengumpulan dan penggunaan informasi oleh guru melalui sejumlah bukti untuk membuat keputusan tentang pencapaian hasil belajar. Dalam kurikulum 2013 digambarkan bahwa penilaian dapat digunakan untuk (1) Hasil belajar yang diperoleh dari penilaian oleh pendidik digunakan untuk menentukan kenaikan kelas peserta didik. (2) Peserta didik dinyatakan tidak naik kelas apabila hasil belajar dari paling sedikit 3 (tiga) mata pelajaran pada kompetensi pengetahuan, keterampilan belum tuntas dan/atau sikap belum baik. (3) Ketentuan sebagaimana dimaksud pada ayat (1) dan ayat (2) tidak berlaku bagi peserta didik SDLB/SMPLB/ SMALB/SMKLB.

Hasil pengajaran yang dimaksud sebagaimana disebutkan di atas dapat berupa dampak pengajaran dan dampak pengiring. Dampak pengajaran merupakan hasil yang dapat diamati langsung sesaat setelah proses pembelajaran dan penilaian dilaksanakan. Sedangkan dampak pengiring, hasil yang tidak dapat diamati langsung sesaat setelah proses pembelajaran berlangsung. Dampak pengiring ini umumnya memerlukan waktu lebih untuk ditemukan melalui pengamatan guru, karena berkaitan dengan perubahan prilaku (Dimyati dan Mudjiono : 2013). Contoh; dampak pengajaran dapat berbentuk nilai dalam data angka seperti 7, 8, 9 dan huruf A, B, C, D, E. sedangkan dampak pengiring dapat dideskripsikan dakam bentuk data verbal yang sangat tergantung dari hasil pengematan terhadap perkembangan siswa.

Dari sisi istilah terdapat istilah pengukuran, evaluasi dan penilaian. Dalam pengukuran dikenal dua macam pengukuran yaitu pengukuran yang terstandar seperti menggunakan meter, kilometer, gram, kilogram, liter, derajat dan lain sebagainya. Ada pula pengukuran yang tidak terstandar misalnya menggunakan depa, langkah, jengkal dan lainnya. Pengukuran 
biasanya bersifat kuantitatif, seperti berat gula itu 2 (dua) kilogram, 10 (sepuluh) kilometer dan seterusnya. Penilaian umumnya keputusan yang diambil berdasarkan pengalaman, misalnya jika air panas dituangkan kedalam gelas yang terbuat kaca, maka panasnya akan lebih lama dibandingkan dengan air panas yang dituangkan ke dalam gelas yang terbuat dari keramik. Sedangkan evaluasi merupakan kegiatan yang dilaksanakan dengan melalui dua kegiatan yaitu pengukuran dan penilaian (H. Daryanto: 2010).

Evaluasi yang dilakukan guru di sekolah, sekurang-kurangnya dimaksudkan untuk (1) mengetahui penguasaan siswa terhadap materi pembelajaran dan (2) mengetahui keefektifan proses pembelajaran yang telah berlangsung. Selain itu evaluasi juga dimaksudkan untuk mengetahui dampak penguasaan siswa terhadap perubahan prilaku siswa dalam kehidupan sehari-hari, baik di sekolah maupun di lingkungan sekitarnya. Sebagai sebuah kegiatan integeral, maka evaluasi tidak dapat dipisahkan dari proses pembelajaran. Evaluasi tidak sekedar untuk mengukur penguasaan siswa terhadap materi pembelajaran, tetapi evaluasi dimaksudkan untuk memantau efektifitas proses, memantau perubahan sikap dan prilaku yang terjadi pada siswa. Dengan demikian dalam pelaksanaan evaluasi bukan saja guru yang berkepentingan, tetapi juga menjadi tanggunjawab siswa, juga orang tua siswa.

Jika setelah penilaian dilaksanakan diperoleh hasil belajar siswa tidak sesuai atau tidak mencapai batas minimal kriteria yang telah ditetapkan, tidak berarti kesalahan terletak pada siswa semata, dapat saja disebabkan oleh proses pembelajaran yang kurang atau tidak tepat, yang dalam istilah pembelajaran disebut sebagai pembelajaran tidak efektif.

Dalam Permendikbud Nomor 66 tahun 2013 dijelaskan bahwa Penilaian pendidikan sebagai proses pengumpulan dan pengolahan informasi untuk mengukur pencapaian hasil belajar peserta didik mencakup: penilaian autentik, penilaian diri, penilaian berbasis portofolio, ulangan, ulangan harian, ulangan tengah semester, ulangan akhir semester, ujian tingkat kompetensi, ujian mutu tingkat kompetensi, ujian nasional, dan ujian 
sekolah/madrasah (Permendikbud 66 tahun 2013), yang diuraikan sebagai berikut. Dalam kajian teori ini terbatas pada mendeskripsikan penilaian autentik. Penilaian autentik merupakan penilaian yang dilakukan secara komprehensif untuk menilai mulai dari masukan (input), proses, dan keluaran (output) pembelajaran (Permendikbud Nomor 66 Tahun 2013). Penilaian autentik (Authentic Assessment) adalah pengukuran yang bermakna secara signifikan atas hasil belajar peserta didik untuk ranah sikap, keterampilan, dan pengetahuan. Istilah autentik merupakan sinonim dari asli, nyata, valid, atau reliabel. Secara konseptual penilaian autentik lebih bermakna secara signifikan dibandingkan dengan tes pilihan ganda terstandar sekalipun. Penilaian autentik juga diartikan sebagai proses pengumpulan informasi oleh guru tentang perkembangan dan pencapaian pembelajaran yang dilakukan anak didik melalui berbagai teknik yang mampu mengungkapkan, membuktikan atau menunjukkan secara tepat pada tujuan pembelajaran dan kemampuan (kompetensi) telah benar-benar dikuasai dan dicapai (Bahrul Hayat, dkk : 2008).

Penilaian autentik ini sebenarnya juga ditemukan dalam kurikulum sebelumnya. Penilaian yang dilaksanakan harus mencakup kawasan afektif, kognitif dan psikomotor yang menjadi kehendak penilaian autentik dengan berbagai teknik yang menjamin dapat memberikan informasi tentang siswa. Penilaian autentik juga didapatkan pada beberapa penjelasan tentang penilaian berbasis kelas yang terdiri dari tes dan non tes. Penilaian tes atau disebut juga paper and pen penilaian yang umumnya digunakan untuk penilaian kognitif, seperti penilaian dengan jenis uraian singkat, pilihan ganda, benar-salah, dan penilaian lainnya. Sedangkan penilaian non tes dapat berupa performance tes, penilaian produk, penilaian proyek dan portofolio.

\section{PENILAIAN HASIL BELAJAR}

Penilaian dalam kegiatan pembelajaran yang umumnya dikenal dengan penilaian hasil belajar, haruslah dapat memberikan makna, baik bagi guru, siswa dan orang tua siswa. Oleh karena itu penilaian hasil belajar seharusnya dapat dilaksanakan melalui berbagai cara, dengan tujuan seluruh aspek baik kognitif, prsikomotorik dan afektif siswa dapat diketahu 
Wildan (2017). PELAKSANAAN PENILAIAN AUTENTIK ASPEK PENGETAHUAN, SIKAP DAN KETERAMPILAN DI SEKOLAH ATAU MADRASAH. JURNAL TATSQIF, 15(2), Retrieved from: http://ejurnal.iainmataram.ac.id/index.php/tatsqif/article/view/1459.

perkembangannya oleh guru, siswa sendiri dan orang tua. Bagi guru hasil penilaian akan dapat digunakan untuk melakukan perbaikan-perbaikan baik dari perencanaan pembelajaran, pelaksanaan proses pembelajaran, maupun sistem penilaian yang dilaksanakan. Bagi siswa tentunya hasil penilaian akan dapat dijadikan sebagai bahan pijakan untuk termotivasi untuk memperbaiki cara-cara belajar yang selama ini siswa lakukan. Bagi orang tua siswa, dapat dijadikan sebagai bahan informasi tentang perkembangan anak khususnya di sekolah, sehingga dapat mengambil langkah-langkah antisipatif dan dorongan bermakna bagi anak untuk meningkatkan hasil belajarnya.

Dalam Permendikbud Nomor 32 tahun 2013, perubahan PP nomor 19 tahun 2005 tentang Standar Nasional Pendidikan Pasal 22 ayat 2 menyebutkan Teknik penilaian sebagaimana dimaksud pada ayat (1) dapat berupa tes tertulis, observasi, tes praktek, dan penugasan perseorangan atau kelompok (Amandemen Standar Nasional Pendidikan : 2015). Dengan penilaian yang dilakukan melalui berbagai cara tersebut memungkinkan akan dapat memperoleh hasil yang komprehensif, dimana guru dapat menggali berbagai informasi dari siswa, yang kemudian dikenal dengan penilaian kelas. Menurut Wina Sanjaya bahwa pertama penilaian kelas (penilaian berbasis kelas) merupakan bagian integeral dalam proses pembelajaran, artinya penilaian ini dilakukan secara terus menerus dalam setiap kegiatan pembelajaran yang dilakukan siswa, baik di dalam kelas maupun di luar kelas, seperti laboratorium atau di lapangan ketika siswa sedang melakukan proses pembelajaran. Kedua; penilaian berbasis kelas merupakan proses pengumpulan informasi yang menyeluruh, artinya dalam penilaian berbasis kelas, guru dapat mengembangkan berbagai jenis evaluasi, baik evaluasi yang berkaitan dengan pengujian dan pengukuran tingkat kognitif siswa seperti menggunakan tes, maupun evaluasi terhadap perkembangan mental melalui penilaian tentang sikap, dan evaluasi terhadap produk atau karya siswa.

Ketiga, hasil pengumpulan informasi dimanfaatkan untuk menetapkan tingkat penguasaan tingkat kompetensi baik standar kompetensi, kompetensi dasar, dan indicator hasil belajar seperti terdapat dalam kurikulum. Keempat, 
hasil pengumpulan informasi digunakan untuk meningkatkan hasil belajar siswa melalui proses perbaikan kualitas pembelajaran agar lebih efektif dan efisien (Wina Sanjaya : 2006).

Mengacu pada pandangan di atas, bahwa penilaian yang dilakukan guru secara terus menerus, memungkinkan guru akan memperoleh data dan informasi yang konprehensif tentang siswa. Penilaian oleh guru secara terus menerus dalam setiap kegiatan pembelajaran juga akan mendapatkan gambaran secara utuh tentang perkembangan siswa terutama mengenai perkembangan sikap dan keterampilan. Oleh karena itu penilaian yang dilaksanakan secara menyeluruh, maka berbagai jenis penilaian harus disiapkan oleh guru, sehingga seluruh perkembangan siswa baik efektif, pengetahuan dan keterampilan dapat direkam dengan baik.

Mulyasa menyebutkan bahwa penilaian kelas dilakukan dengan ulangan harian, ulangan umum dan ujian akhir. Ulangan harian dilakukan setiap selesai proses pembelajaran dalam kompetensi dasar tertentu. Ulangan harian minimal dapat dilakukan sebanyak tiga kali dalam setiap semester, terutama ditujukan untuk memperbaiki program pembelajaran, akan tetapi tidak menutup kemungkinan digunakan untuk tujuan-tujuan lain, misalnya sebagai bahan pertimbangan dalam memberikan nilai bagi para peserta didik (E. Mulyasa : 2007).

Ulangan umum dilaksanakan setiap akhir semester, dengan ketentuan soal-soal ulangan semester pertama diambil dari materi semester pertama, sedangkan soal-soal ulangan semester kedua merupakan gabungan materi semester pertama dan kedua, dengan penekanan pada materi semester kedua. Ujian akhir dilakukan pada akhir program pendidikan. Bahan-bahan yang diujikan meliputi seluruh kompetensi dasar yang diberikan, dengan tujuan untuk menentukan kelulusan bagi setiap peserta didik, dan layak tidaknya untuk melanjutkan pendidikan di atasnya. Dalam PP 32 tahun 2013 juga menjelaskan bahwa penilaian hasil belajar sebagaimana dimaksud pada ayat (1) untuk semua mata pelajaran dilakukan melalui ujian sekolah/madrasah untuk menentukan kelulusan peserta didik dari satuan pendidikan (Amandemen Standar Nasional Pendidikan : 2015). 
Lebih lanjut Mulyasa menjelaskan bahwa penilaian kelas dilakukan oleh guru untuk mengetahui kemajuan dan hasil belajar peserta didik, mendiagnosa kesulitan belajar, memberikan umpan balik untuk perbaikan proses pembelajaran dan penentuan kenaikan kelas (E. Mulyasa : 2007).

Ulangan harian, ulangan umum maupun ujian akhir tidak hanya mengukur, menilai dan mengevaluasi ranah kognitif siswa, akan tetapi harus dapat mengukur ranah afektif dan psikomotorik. Ketiga aspek tersebut memiliki instrument yang digunakan untuk menilai, yang dikembangkan oleh guru. Hal inilah yang kemudian diatur dalam peraturam pemerintah bahwa penilaian dilaksanakan dengan menggunakan berbagai teknik berupa tes tertulis, observasi, tes praktek, dan penugasan perseorangan atau kelompok.

Dalam Permendikbud 104 tahun 2014 tentang Penilaian Hasil Belajar menjelaskan bahwa penilaian Hasil Belajar oleh Pendidik adalah proses pengumpulan informasi/bukti tentang capaian pembelajaran peserta didik dalam kompetensi sikap spiritual dan sikap sosial, kompetensi pengetahuan, dan kompetensi keterampilan yang dilakukan secara terencana dan sistematis, selama dan setelah proses pembelajaran. Kewajiban guru dalam melakukan penilaian haruslah konprehensif, bahkan di dalam kurikulum 2013 penilaian terhadap aspek sikap dikembangkan menjadi penilaian aspek sikap spiritual dan sikap social yang di dalam kompetensi inti tertuang dalam kompetensi inti satu (KI-1) dan kompetensi inti dua (KI-2), dan harus melakukan penilaian kepada dua kompetensi yaitu kompetensi pengetahuan dan kompetensi keterampilan.

Penilaian bagi siswa dimungkinkan dapat menggunakan berbagai bentuk penilaian, seperti penilaian tertulis, penilaian unjuk kerja, penilaian produk, dan penilaian proyek. Instrument yang dapat digunakan adalah instrument tes dan skala sikap, sedangkan tekniknya dapat berupa tes tertulis, tes lisan, prkatek, dan pengamatan. Penilaian yang diungkapkan di atas selama ini sering dikenal ke dalam dua jenis penilaian yaitu tes dan non tes. 
Penilaian, baik tes maupun non tes adalah penilaian untuk mendapatkan hasil belajar oleh guru sebagai pendidik. Penilaian hasil belajar oleh pendidik memiliki fungsi formatif dan sumatif, yaitu :

- Untuk memantau kemajuan belajar siswa;

- mendeteksi kebutuhan perbaikan hasil belajar peserta didik secara berkesinambungan, dan

- memantau hasil belajar.

Sedangkan tujuannya adalah untuk:

- mengetahui tingkat penguasaan kompetensi;

- menetapkan ketuntasan penguasaan kompetensi;

- menetapkan program perbaikan atau pengayaan berdasarkan tingkat penguasaan kompetensi; dan

- memperbaiki proses pembelajaran.

Keseluruhan penilaian yang direncanakan dan dikembangkan, serta dilaksanakan guru harus memperhatikan prinsip-prinsip peniaian yang meliputi :

- sahih, berarti penilaian didasarkan pada data yang mencerminkan kemampuan yang diukur;

- objektif, berarti penilaian didasarkan pada prosedur dan kriteria yang jelas, tidak dipengaruhi subjektivitas penilai;

- adil, berarti penilaian tidak menguntungkan atau merugikan peserta didik karena berkebutuhan khusus serta perbedaan latar belakang agama, suku, budaya, adat istiadat, status sosial ekonomi, dan gender;

- terpadu, berarti penilaian oleh pendidik merupakan salah satu komponen yang tak terpisahkan dari kegiatan pembelajaran;

- terbuka, berarti prosedur penilaian, kriteria penilaian, dan dasar pengambilan keputusan dapat diketahui oleh pihak yang berkepentingan;

- menyeluruh dan berkesinambungan, berarti penilaian oleh pendidik mencakup semua aspek kompetensi dengan menggunakan berbagai teknik penilaian yang sesuai, untuk memantau perkembangan kemampuan peserta didik; 
- sistematis, berarti penilaian dilakukan secara berencana dan bertahap dengan mengikuti langkah-langkah baku;

- beracuan kriteria, berarti penilaian didasarkan pada ukuran pencapaian kompetensi yang ditetapkan; dan

- akuntabel, berarti penilaian dapat dipertanggungjawabkan, baik dari segi teknik, prosedur, maupun hasilnya.

\section{PENILAIAN AUTENTIK (AUTHENTIC ASESSMENT)}

Dalam Permendikbud nomor 104 tahun 2014 menjelaskan bahwa penilaian autentik adalah bentuk penilaian yang menghendaki peserta didik menampilkan sikap, menggunakan pengetahuan dan keterampilan yang diperoleh dari pembelajaran dalam melakukan tugas pada situasi yang sesungguhnya. Dalam kurikulum 2013 penilaian autentik meliputi penilaian kompetensi sikap kompetensi pengetahuan dan kompetensi keterampilan.

\section{Penilaian Kompetensi Sikap}

Sikap merupakan kecenderungan seseorang dalam merespon sesuatu atau obyek, yang tergambar melalui rasa suka, tidak suka, setuju dan setuju. Penilaian sikap dapat dilakukan dengan cara pengamatan (observasi), penilaian diri, penilaian teman sejawat dan rekaman anekdot (catatan anekdot). Penilaian melalui observasi bertujuan untuk merekam perkembangan sikap siswa melalui pengamatan, baik sikap siswa terhadap mata pelajaran atau sikap terhadap hal umum. Misalnya mengamati sikap siswa mengenai kedisiplinan, ketekunan, kejujuran, kerjasama dan lain sebagainya. Format pengamatan dapat dikembangkan sendiri oleh guru atau mengacu kepada beberapa contoh pedoman pengamatan yang diperoleh melalui literatur-literatur tentang penilaian pembelajaran. Penilaian diri, merupakan penilaian yang berkembang akibat bergesernya system pembelajaran dari pembelajaran yang berpusat pada guru ke pembelajaran yang berpusat pada siswa. Supaya siswa dalam penilaian diri tidak mengedepankan subyektivitas sehingga tidak menilai diri terlalu tinggi, maka guru harus melakukan hal-hal sebagai berikut: (1) menjelaskan tujuan penilaian diri, (2) menentukan kompetensi yang akan dinilai, (3) 
menentukan indicator dan skala penilaiannya, dan (4) menentukan format penilaian diri.

Penilaian sejawat-penilaian teman sebaya (peer assessment) merupakan kesempatan yang diberikan kepada siswa untuk menilai teman sebayanya atau mereka berkesempatan saling menilai antar teman sebayanya. Agar penilaian ini tetap menilai hal-hal yang seharusnya, guru harus mengembangkan format penilaian dimana siswa cukup memberikan jawaban atas pernyataan yang telah dikembangkan guru sesuai dengan indicator yang telah ditetapkan. Misalnya tentang kejujuran, kedisplinan, ketaatan melaksanakan tata tertib, kerjasama dan lainnya. Penilaian diri dan penilaian sejawat harus dapat dilakukan sekurang-kurangnya satu kali dalam setiap semester.

Penilaian sikap terdiri dari (1) penilaian sikap utama, dan (2) penilaian sikap penunjang. Penilaian pada sikap utama dilakukan melalui observasi oleh guru mata pelajaran, guru bimbingan konseling dan wali kelas selama satu semester. Observasi sikap oleh guru mata pelajaran dalam satu semester tersebut dilakukan selama dalam proses pembelajaran maupun di luar proses pembelajaran. Sedangkan observasi oleh guru bimbingan konseling dan wali kelas, dilakukan dalam satu semester di luar jam pelajaran baik secara langsung maupun berdasarkan informasi atau laporan yang valid. Penilain sikap penunjang terdiri dari penilaian diri dan penilaian antar teman (penilaian sejawat) yang dapat dilaksanakan sekurangkurangnya satu kali selama satu semester. Dalam bentuk skema dapat digambarkan sebagai berikut: 


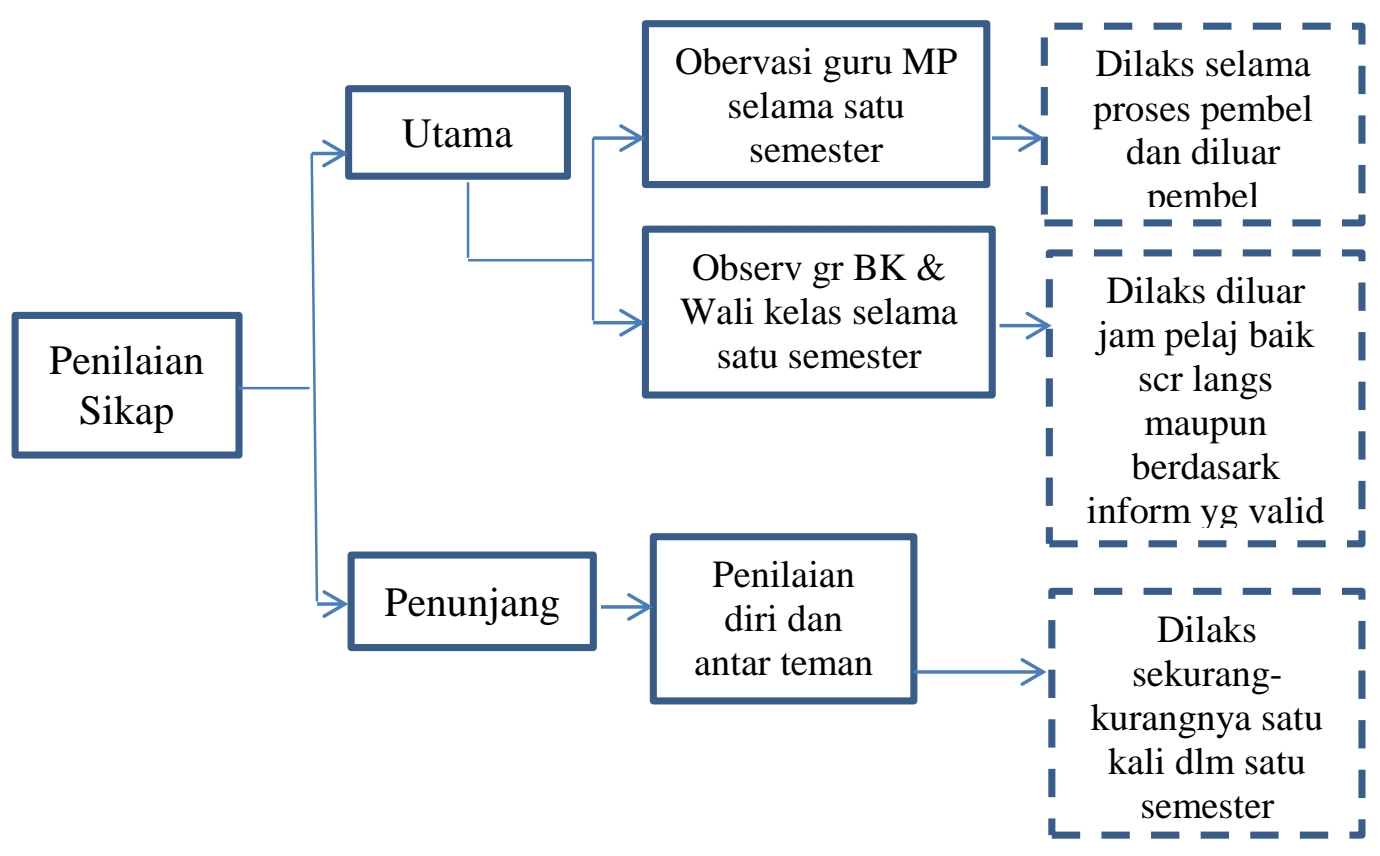

Gambar 1: Skema Penilaian Aspek Sikap

\section{Penilaian Kompetensi Pengetahuan}

Penilaian kompetensi pengetahuan merupakan aspek penilaian yang sudah sangat dikenal oleh para guru. Penilaian kompetensi pengetahuan ini salah satunya meliputi tes tulis seperti pilihan ganda, menjodohkan, benarsalah, melengkapi, uraian singkat dan masih banyak lagi beberapa jenis dan teknik dalam tes tulis untuk penilaian kompetensi pengetahuan. Soal tes tertulis yang menjadi penilaian autentik adalah soal-soal yang menghendaki peserta didik merumuskan jawabannya sendiri, seperti soal-soal uraian. Soalsoal uraian menghendaki peserta didik mengemukakan atau mengekspresikan gagasannya dalam bentuk uraian tertulis dengan menggunakan kata-katanya sendiri, misalnya mengemukakan pendapat, berpikir logis, dan menyimpulkan. Setiap jenis penilaian ini memiliki kelebihan dan kelemahan. Misalnya kelebihan dari tes dalam bentuk uraian, adalah lebih mudah dalam mengembangkannya, dan memancing siswa untuk dapat mengembangkan cara berpikir, serta melatih kemampuan berpikir kritis. Kelemahan tes tertulis bentuk uraian antara lain cakupan materi yang ditanyakan terbatas dan membutuhkan waktu lebih banyak dalam 
mengoreksi jawaban. Selain itu memiliki unsur subyektifitas dari penilai yang sulit dihindari.

Penilaian dengan jenis pilihan ganda memiliki kelebihan antara lain memiliki unsur obyektifitas yang tinggi, dapat melingkupi cukup banyak materi yang telah dipelajari siswa, dan mudah dalam mengoreksi. Sedangkan kelemahannya antara lain, memerlukan kecermatan dalam menyusun tesnya, lemah dalam melatih siswa untuk berpikir kritis, hanya dapat mengukur kemampuan siswa pada tingkat kognitif yang paling rendah.

Penilaian pengetahuan dapat dilaksanakan dengan berbagai teknik, seperti tes tulis, tes lisan, penugasan dan teknik lain misalnya melalui protofolio dan observasi. Dengan teknik tes tulis dapat menggunakan beberapa jenis penilaian seperti benar salah, pilihan ganda, menjodohkan, isian/melengkapi, dan uraian. Penilaian dengan tes lisan dapat dilakukan dengan kuis dan tanya jawab, sedangkan melalui teknik penugasan dapat dilakukan dengan tugas yang dilakukan secara individu maupun kelompok di dalam satuan pendidikan atau di luar sekolah. Skema penilaian ini dapat digambarkan sebagai berikut:

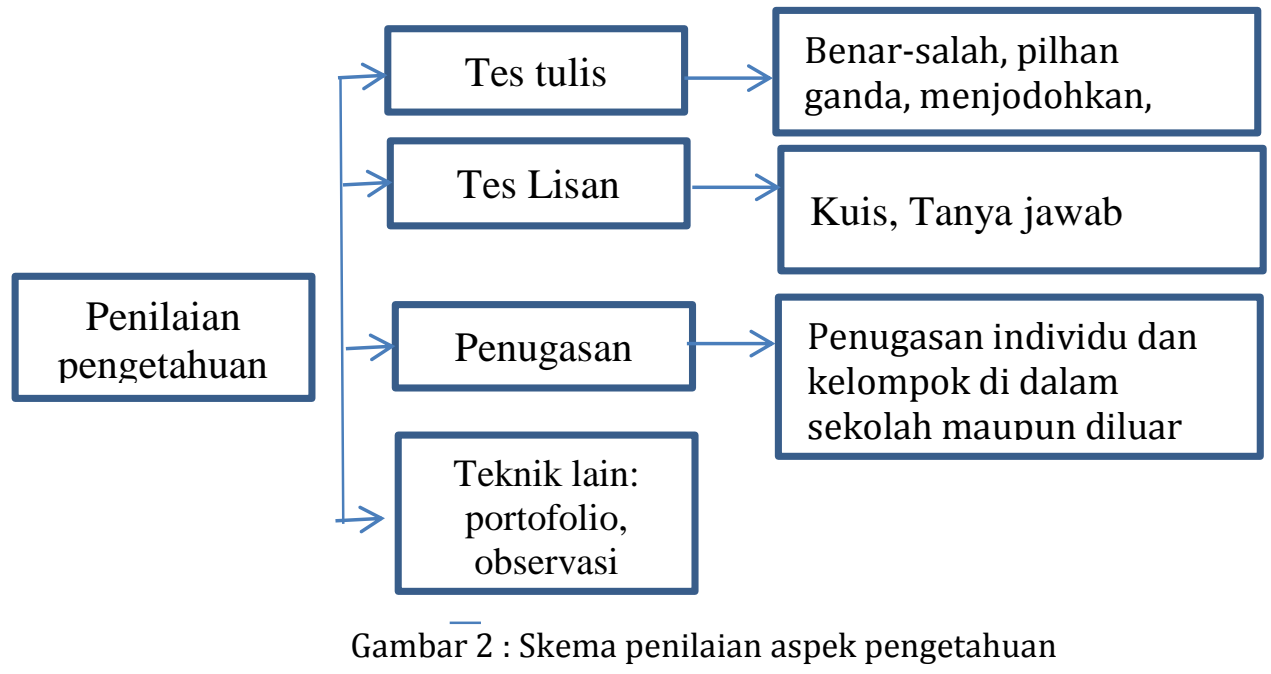

\section{Penilaian Kompetensi Keterampilan}

Penilaian keterampilan dapat dilakukan dengan cara-cara seperti (1) penilian unjuk kerja, yaitu penilaian untuk mengamati kegiatan siswa dalam menerapkan sesuatu yang dapat diamati, seperti unjuk kerja dalam melaksanakan shalat, membaca puisi, membaca surat-surat pendek, praktik 
olahraga, berpidato dan lain sebagainya. (2) penilaian proyek, yaitu penilaian yang diberikan kepada siswa dalam melaksanakan tugas dalam waktu tertentu, untuk mengukur pemahaman siswa dalam melakukan penyelidikan. Penilaian ini dapat meliputi perencanaan termasuk mengembangkan desain, pengumpulan data, pengolahan data, sampai kepada pelaporan hasil penyelidikan. (3) penilaian produk, penilaian hasil karya siswa misalnya berupa hasil karya berupa lukisan, kaligrafi, membuat kue, membuat alat musik, alat kebersihan dan lainnya.

Penilaian pada aspek keterampilan tersebut yang dilakukan melalui penilaian unjuk kerja/kinerja/praktik, penilaian produk, penilaian proyek, penilaian portofolio, atau dapat menggunakan teknik lain misalnya melalui tes.

Penilaian keterampilan melalui penilaian unjuk kerja/kinerja/ praktik adalah penilaian yang dilakukan dengan cara mengamati kegiatan peseta didik, penilaian keterampilan melalui penilaian produk adalah penilaian terhadap kemampuan peserta didik dalam membuat produk-produk (hasil karya) teknologi maupun seni. Penilaian keterampilan melalui penilaian proyek merupakan penilaian terhadap kegiatan penyelidikan yang meliputi perencanaan, pelaksanaan dan pelaporan dalam jangka waktu tertentu. Sedangkan penilaian portofolio adalah penilaian yang berupa rekaman hasil pembelajaran dan penilaian yang memperkuat kemajuan dan kualitas pekerjaan siswa.

Skema penilaian aspek keterampilan ini dapat digambarkan sebagai berikut : 


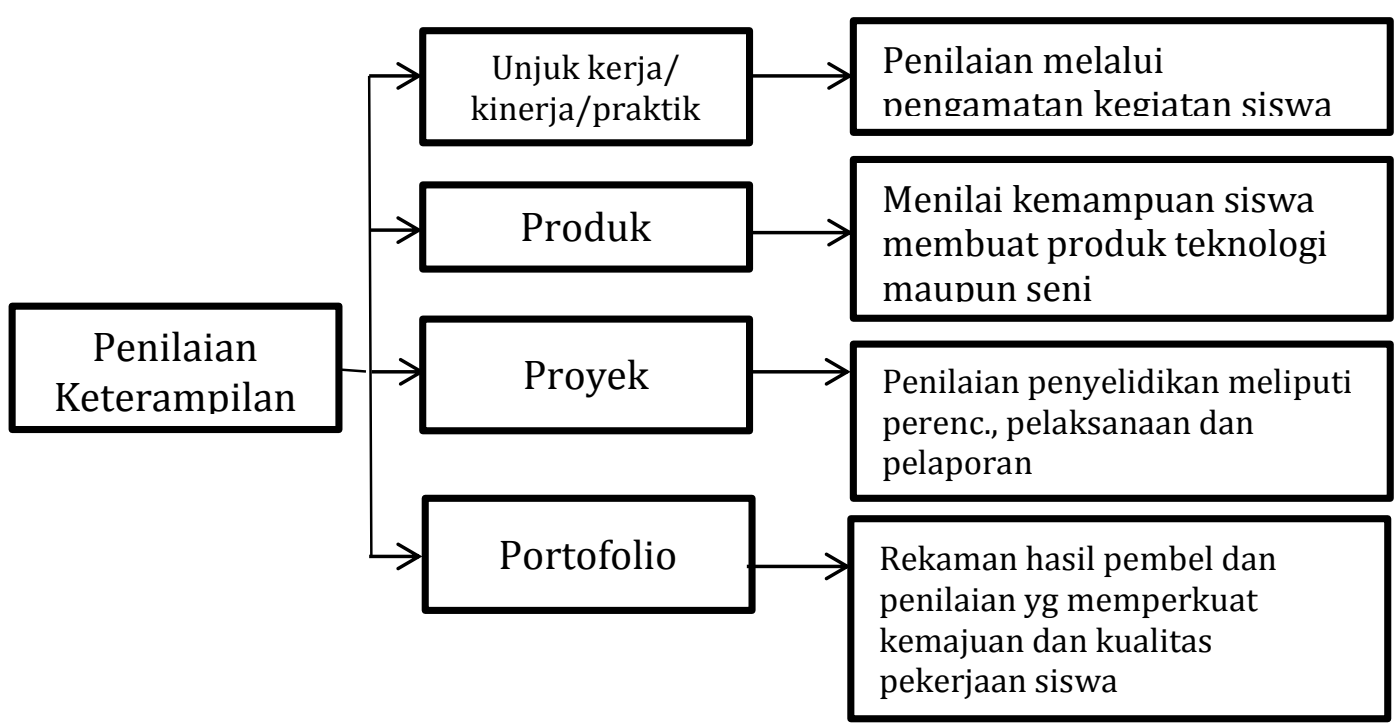

Gambar 3 : Skema Penilaian Aspek Keterampilan

\section{PENGOLAHAN NILAI HASIL BELAJAR}

Sebelum guru mengambil keputusan terhadap siswa berdasarkan hasil evaluasi, maka hasil penilaian yang telah dilaksanakan harus melalui pengolahan dan dianalisis terlebih dahulu. Pada bagian ini akan dideskripsikan tentang pengolahan nilai, baik pengolahan nilai sikap, nilai pengetetahuan dan keterampilan.

\section{Pengolahan Nilai Sikap}

Beberapa hal yang perlu diperhatikan dalam pengolahan nilai pada aspek sikap antara lain:

- Pengolahan nilai kompetensi sikap (KD pada KI 1 dan KI 2) dilakukan pada akhir semester.

- Nilai kompetensi sikap diperoleh melalui teknik observasi yang dicatat dalam teknik jurnal dan dapat didukung oleh teknik penilaian lainnya (penilaian diri, penilaian antarteman, dsb).

- Nilai kompetensi sikap pada akhir semester diperoleh dari semua nilai sikap sesuai kompetensi dasar semester bersangkutan (sesuai perencanaan dan pemetaan).

- Nilai kompetensi sikap disampaikan dalam bentuk deskripsi.

Data mengenai sikap yang telah diperoleh harus memperhatikan sumber datanya. Adapun sumber-sumber data untuk nilai sikap adalah: 
- Guru mata pelajaran melalui observasi yang dicatat dalam jurnal selama proses pembelajaran;

- Guru Bimbingan Konseling melalui observasi langsung yang dicatat dalam jurnal nilai maupun tidak langsung (laporan pihak lain) yang dicatat juga pada jurnal penilaian;

- Wali kelas merekap hasil deskripsi dari guru mata pelajaran dan guru Bimbingan Konseling dan merumuskan kembali deskripsi nilai sikap spiritual dan sikap sosial.

Adapun contoh jurnal yang dapat digunakan untuk merekam perkembangan sikap siswa sebagai berikut:

Tabel 1: Jurnal Perkembangan Sikap

Nama Sekolah

Kelas / Semester

Tahun Pelajaran :

\begin{tabular}{|l|l|l|l|l|l|}
\hline No & Waktu & $\begin{array}{r}\text { Nama } \\
\text { Siswa }\end{array}$ & \multicolumn{1}{|c|}{ Catatan Perilaku } & Butir Sikap & Ket. \\
\hline 1. & $\begin{array}{l}\text { Senin, } \\
\text { Juli 2016 }\end{array}$ & Ahdiyat & $\begin{array}{l}\text { Tidak mengikuti } \\
\text { kegiatan sholat zhuhur } \\
\text { berjamaah di sekolah }\end{array}$ & Ketaqwaan & Spritual \\
\hline 2. & $\begin{array}{l}\text { Senin Juli } \\
2016\end{array}$ & Safaira & $\begin{array}{l}\text { Mengajak temannya } \\
\text { untuk mengunjungi Rita } \\
\text { yang sakit setelah } \\
\text { pembelajaran disekolah } \\
\text { selesai }\end{array}$ & Kepedulian & Sosial \\
\hline 3. & $\begin{array}{l}\text { Sabtu, } \\
\text { Agustus } \\
2016\end{array}$ & Khairul & $\begin{array}{l}\text { Menyerahkan dompet } \\
\text { yang dipungut di kantin } \\
\text { kepada satpam sekolah }\end{array}$ & Kejujuran & Sosial \\
\hline
\end{tabular}

Setelah data nilai sikap diperoleh dari sumber sebagaimana di atas, baru kemudian dilakukan proses pengolahan nilai sikap. Pengolahan nilai sikap ini dengan tahapan sebagai berikut:

- Guru mata pelajaran dan guru Bimbingan Konseling mencatat perilaku sikap spiritual dan sikap sosial ke dalam jurnal. 
- Guru mata pelajaran dan guru Bimbingan Konseling membuat rumusan deskripsi singkat sikap spiritual dan sikap sosial berdasarkan catatan jurnal untuk setiap siswa, kemudian memberikan kepada wali kelas.

- Wali kelas mengumpulkan deskripsi singkat sikap dari guru mata pelajaran dan guru Bimbingan Konseling. Berdasarkan deskripsi singkat sikap spiritual dan sosial dari guru mata pelajaran, guru Bimbingan Konseling, wali kelas merumuskan deskripsi capaian sikap spiritual dan sosial setiap siswa.

Jika pengolahan telah dilaksanakan melalui tiga tahapan sebagaimana di atas, selanjutnya guru menuliskan hasil pengolahan tersebut dalam bentuk deskripsi yang akan dituangkan ke dalam rapor siswa. Rumusan deskripsi nilai sikap ditulis dalam kalimat yang bersifat memotivasi dan menyatakan nilai sikap secara berturut dari sangat baik, baik, dan mulai berkembang. Contoh deskripsi nilai aspek sikap sebagai berikut:

Menunjukkan sikap sangat baik dalam mensyukuri anugerah Tuhan, kejujuran, tanggung jawab, dan kesantunan; baik dalam menghargai anugerah Tuhan, peduli, dan percaya diri; dan mulai berkembang sikap disiplin.

\section{Pengolahan Nilai Kompetensi Pengetahuan}

Sebagaimana penilaian pada kompetensi sikap, pengolahan nilai untuk kompetensi pengetahuan juga harus memperhatikan hal-hal sebagai berikut:

Nilai kompetensi pengetahuan diperoleh dari:

- Penilaian harian (PH), pada setiap akhir pembelajaran suatu KD atau beberapa bagian KD pada KI 3.

- Penilaian tengah semester (PTS), pada minggu ke-7 suatu semester.

- Penilaian akhir semester (PAS), pada akhir suatu semester.

Pengolahan nilai harian pada kompetensi pengetahuan, dapat digambarkan dalam bentuk table sebagaimana contoh berikut:

Tabel 2: Format table pengolahan nilai pengethuan 
Wildan (2017). PELAKSANAAN PENILAIAN AUTENTIK ASPEK PENGETAHUAN, SIKAP DAN KETERAMPILAN DI SEKOLAH ATAU MADRASAH. JURNAL TATSQIF, 15(2), Retrieved from: http://ejurnal.iainmataram.ac.id/index.php/tatsqif/article/view/1459.

\begin{tabular}{|l|l|c|c|c|c|c|c|c|}
\hline \multirow{2}{*}{ No } & \multirow{3}{*}{ Nama } & \multicolumn{3}{|c|}{ Tes Tertulis } & \multicolumn{3}{c|}{ Penugasan } & \multirow{2}{*}{ Rata-rata } \\
\cline { 3 - 8 } & & KD & KD & KD & KD & KD & KD & \\
& & 3.1 & 3.2 & 3.3 & 3.1 & 3.2 & 3.3 & \\
\hline 1. & Dewi & 80 & 70 & 85 & 90 & 82 & 76 & 80,5 \\
\hline$\ldots$ & $\ldots$ & $\ldots$ & $\ldots$ & $\ldots$ & $\ldots$ & $\ldots$ & & \\
\hline
\end{tabular}

Berdasarkan data di atas dapat dihitung nilai penilaian harian 1 dengan rumus :

Jml nilai tes + Jml Nilai Penugasan

Penilaian Harian 1 (PH1) =

Banyaknya Penilaian

Berikut contoh format pengolahan nilai penilaian ahir pada kompetensi pengetahuan sebagaimana table berikut:

Tabel 3 : contoh format pengolahan nilai penilaian ahir pada kompetensi pengetahuan

\begin{tabular}{|l|c|c|c|c|c|}
\hline \multicolumn{1}{|c|}{ Nama } & HPH & HPTS & HPAS & HPA & Pembulatan \\
\hline Yasykur & 73,89 & 90 & 80 & 81,30 & 80 \\
\hline Ridho & 75,56 & 75 & 80 & 76,85 & 77 \\
\hline$\ldots . .$. & & & & & \\
\hline
\end{tabular}

HPH+HPTS+HPAS

$\mathrm{HPA}=$

3

Keterangan:
HPA = Hasil Penilaian Akhir
$\mathrm{HPH}=$ Hasil Penilaian Harian
HPTS = Hasil Penilaian Tengah Semester
HPAS = Hasil Penilaian Akhir Semester 
Untuk pengolahan nilai kompetensi pengetahuan seorang guru harus telah menetapkan rentang nilai untuk kompetensi ini.

Adapun contoh rentang nilai pada pengolahan nilai kompetensi pengetahuan sebagai berikut:

Tabel 4 : Rentang nilai pengolahan nilai kompetensi pengetahuan

\begin{tabular}{|c|c|}
\hline \multicolumn{2}{|c|}{ Pengetahuan } \\
\hline Skor Rerata & Predikat \\
\hline $86-100$ & Sangat Baik (A) \\
\hline $71-85$ & Baik (B) \\
\hline $56-70$ & Cukup (C) \\
\hline$\leq 55$ & Kurang (D) \\
\hline
\end{tabular}

Hasil nilai pada penilaian kompetensi pengetahuan selain dalam bentuk angka juga harus dideskripsikan. Adapun rumusan deskripsi nilai pengetahuan ditulis dalam kalimat yang bersifat memotivasi, menyatakan nilai-nilai pengetahuan secara berturut-turut dari yang sangat baik, baik, dan yang mulai memahami/menguasai.

Contoh deskripsi pada nilai pengetahuan sebagai berikut:

Sangat memahami/menguasai KD .., memahami/menguasai KD ... dan mulai memahami/menguasai KD ....

\section{Pengolahan Penilaian Kompetensi Keterampilan}

Nilai akhir pada kompetensi keterampilan diperoleh dengan cara sebagai berikut:

- Tentukan nilai optimal (tertinggi) untuk masing-masing KD. Untuk KD yang hanya dilakukan sekali penilaian, hasilnya berlaku sebagai nilai optimal untuk KD tersebut.

- Buat tabel untuk mendokumentasikan seluruh hasil penilaian keterampilan selama satu semester.

- Masukkan seluruh hasil penilaian tersebut sesuai dengan teknik yang digunakan.

- Hitung jumlah nilai optimal dari seluruh KD untuk mendapatkan jumlah skor yang diperoleh 
Sebagaimana dalam penilaian kompetensi pengetahuan, penilaian pada kompetensi keterampilan juga ditetapkan konversi nilai dan predikat. Berdasarkan seluruh pengolahan nilai pada penilaian keterampilan dan dianalisis menggunakan table konversi, baru kemudian memberikan deskripsi berdasarkan atas hasil pengolahan nilai yang diperoleh. Rumusan deskripsi nilai pengetahuan ditulis dalam kalimat yang bersifat memotivasi, menyatakan nilai-nilai ketrampilan secara berturut-turut dari yang sangat baik, baik, dan yang mulai memahami/menguasai. Contoh deskripsi pada penilaian keterampilan sebagai berikut:

Sangat terampil . (diisi sesuai KD dari KI 4) terampil (diisi sesuai KD dari KI 4) dan mulai trampil (diisi sesuai KD dari KI 4)

\section{KESIMPULAN}

Penilian merupakan bagian integral dari proses pembelajaran, sebagai komponen yang tidak terpisahkan penilaian harus direncanakan sejak awal sebelum kegiatan pembelajaran dilaksanakan. Penilaian harus bersifat konprehensif, untuk mendapatkan informasi pada seluruh aspek perkembangan siswa baik aspek kognitif, afektif, maupun psikomotorik. Penilaian yang dilakukan secara komprehensif adalah penilaian autentik yang merupakan penilaian untuk menilai sejak awal (input), proses dan keluaran (output) pembelajaran.

Penilaian autentik secara konseptual lebih bermakna siginifikan dibandingkan dengan tes terstandar. Penilaian autentik juga diartikan sebagai proses pengumpulan informasi oleh guru tentang perkembangan dan pencapaian pembelajaran yang dilakukan anak didik melalui berbagai teknik yang mampu mengungkapkan, membuktikan atau menunjukkan secara tepat pada tujuan pembelajaran dan kemampuan (kompetensi) telah benar-benar dikuasai dan dicapai. Penilaian autentik juga didapatkan pada beberapa penjelasan tentang penilaian berbasis kelas yang tediri dari tes (paper and pen) dan non tes dapat berupa performance tes, penilaian produk, penilaian proyek dan portofolio. 


\section{DAFTAR PUSTAKA}

Amandemen Standar Nasional Pendidikan (PP. No. 32 Tahun 2013) dilengkapi dengan PP. No. 19 Tahun 2005. (2015). Jakarta: Sinar Grafika.

Hayat,B, dkk. (2008) Assessment Berbasis Kelas. Jakarta: Pusat Penilaian Pendidikan Badan Penelitian dan Pengembangan Departemen Pendidikan Nasional.

Dimyati dan Mudjiono. (2013). Belajar dan Pembelajaran. Jakarta: Rineka Cipta

E. Mulyasa. (2007). Kurikulum Tingkat Satuan Pendidikan Sebuah Panduan Praktis. Bandung: Remaja Rosdakarya.

H. Daryanto. (2010). Evaluasi Pendidikan. Jakarta: Rineka Cipta.

Peraturan Menteri Pendidikan dan Kebudayaan Republik Indonesia Nomor 66 Tahun 2013 tentang Standar Penilaian Pendidikan.

Peraturan Menteri Pendidikan dan Kebudayaan Republik Indonesia Nomor 104 Tahun 2014 tentang Penilaian Hasil Belajar oleh Pendidik pada Pendidikan Dasar dan Pendidikan Menengah.

Sanjaya, W. (2006). Pembelajaran dan Implementasi Kurikulum Berbasis Kompetensi. Jakarta: Prenada Media Grup. 